\title{
CANOPY OF SKULLS
}

\section{When two worlds collide.}

\section{BY BETH CATO}

$\mathrm{M}$ edea trod the patchwork shadow and light beneath the canopy of skulls. Set high on poles, the white bones had turned varying shades of grey and green. Some wore full skins of verdant flora. These were the colony elders, the first generation on Rikyu. Almost 50 skulls, their soulless eye sockets staring at the stars from whence they had come.

As a child, Medea had yearned for her own skull to belong among the canopy. She had come to accept that she was generations too late for such an honour, and now she no longer belonged on Rikyu at all.

Within hours, a shuttle would deliver the 11 surviving colonists to an orbiter. Medea was the youngest at 15, and she itched with restlessness. She had no desire to stay, not since Mama had died the previous winter. And yet, she ached with a need to pay homage to the only home she knew, to these skulls she had adored since childhood.

"Give me a sign," she whispered to her great-great-grandparents above. She was even wearing her furs one final time, so they'd recognize her. "Show me how to honour you."

Birdlings and slither-slips rustled among the ferns. Gnarled vines draped from pole to pole brushed her cheeks. She knew each elder's name as a mantra: Kazuo Uematsu, Mary Brown, Jorge Jimenez and down the line. A few poles were empty, their bones swallowed by the forest.

Her bare feet, callused to stiffleather, paced the familiar furrows below the canopy. Something smooth slid beneath her toe. She paused and picked up a white rock. Odd, to find such a rounded stone so far from the river.

"Forty-nine skulls. Your precious elders. A century on this rock, and these are the most valuable things here. Pathetic."

Medea whirled around. It was Mr Dale, the researcher. He had come down on the shuttle and intended to stay and study the remains of their colony. Her brow furrowed as she struggled to understand him. They both spoke English, but the ship's crew used strange words and formed their tongues in peculiar ways.

"Yes. Forty-nine," she said with a smile, pleased at his interest in the canopy.

He stopped about ten feet away. His pale skin gleamed like sickness, though she knew it was from a lack of natural light. Strange, to think of her own skin turning so pale while travelling through space.

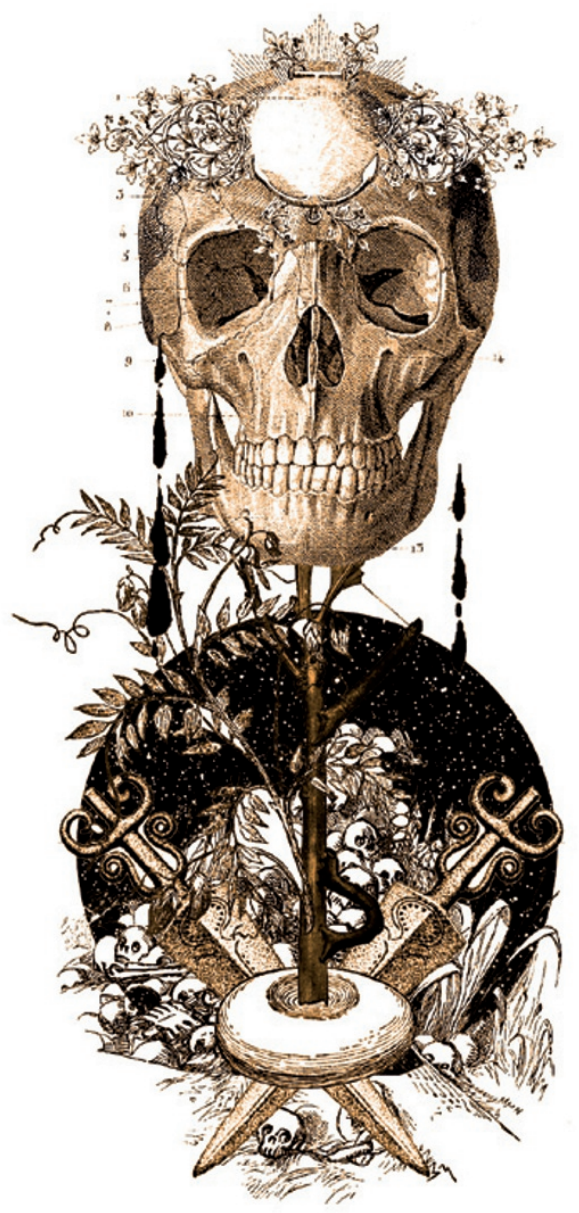

“This is my favourite place," Medea said. "I will miss it most." She blinked back tears.

He tilted an ear as he tried to decipher her words, then shook his head.

"You're not even worth the effort of turning on my translator. Well, you'll be gone soon enough, and those lucky bastards on the ship get to work on civilizing you." He snorted. "Though it'd be funny to see you lot learning about hot showers and ready food, all that. No more hunting, not unless you're going to pelt rocks at a refrigerator." He pointed at her. "Where ... are ... your ... clothes?"

His words and accent tumbled together like mating coati, but the last bit was indeed easier to understand. "At my house. I needed to wear my furs to come here and say good-bye."

Medea did love how her new clothes fit - soft as otterette skin, though strange in how they covered her from neck to ankle.

$\rightarrow$ NATURE.COM Follow Futures: y @NatureFutures f go.nature.com/mtoodm The processed protein nuggets they expected her to eat were not as welcome.

She rubbed the smooth stone in the well of her palm and wondered what the elders wanted of her.

"Ah, little barbarian. It's quite understandable when alien races engage in such practices, but for humans to degrade to ancient meateating-and-wearing days? That's repulsive." He sighed and jerked his hand overhead at the skull of Aamina Mukherjee. "And no concept of money, no concept of worth. This lot crashed on this uncharted, un-terra-formed slag heap, and you may as well have landed in the Mesozoic."

Medea couldn't help but perk up. "That's Aamina! She was a botanist. She cultivated the vines we use for thatching and snares, and genetically tweaked them to reduce skin allergies. Isn't she beautiful with her draping flowers? You're lucky to see her in bloom."

Homesickness knotted in her gut, even though she had yet to leave home. She was so excited to see other worlds, and yet - she envied this man for staying here. She thought on something Mr Dale said - the ship's crew being "lucky bastards". They thought as highly of him. She'd heard the captain say that Mr Dale was a "crooked bastard" who deserved to stay on a planet like Rikyu.

"Look at you," said Mr Dale, laughing. "You're daft. You'll probably end up whoring on Janero. You have no idea that something like this - this bone on a stick - will sell for a million genny-slips because of the story and tragedy of this place. You're a newfangled Donner Party. I'll make my fortune here." He gripped a vacant pole, grinning.

Here. The depth of meaning in that one word resonated. Sunlight sliced through the opening in the canopy and illuminated his bare head. Birdlings hushed. Medea smiled acknowledgment to the skulls and to $\mathrm{Mr}$ Dale's fervent request.

The rock flew from her hand. His skull cracked, sound reverberating through the canopy. Mr Dale tumbled backwards with a crackle of underbrush.

"You are a first generation to come here! If I could stay with the elders, I would. You are lucky to belong here!"

Tears filled her eyes as she unsheathed her knife. She had just enough time to set him on a pole. Medea gazed up at the heavens, like the skulls around her, and watched for the glint of the orbiter above.

Beth Cato resides in Arizona. Her work can be found in Daily Science Fiction and Flash Fiction Online. For information on her latest projects, please visit www. bethcato.com. 